\title{
KESEJAHTERAAN KELUARGA DAN KUALITAS LINGKUNGAN PENGASUHAN PADA ANAK USIA PRASEKOLAH
}

\author{
Elmanora $^{\left.1^{*}\right)}$, Dwi Hastuti ${ }^{2}$, Istiqlaliyah Muflikhati ${ }^{2}$ \\ ${ }^{1}$ Program Studi IImu Keluarga dan Perkembangan Anak, Sekolah Pascasarjana Institut Pertanian Bogor, \\ Bogor 16680, Indonesia \\ ${ }^{2}$ Departemen IImu Keluarga dan Konsumen, Fakultas Ekologi Manusia, Institut Pertanian Bogor, \\ Bogor 16680, Indonesia \\ *)E-mail:elma.nora@yahoo.com
}

\begin{abstract}
Abstrak
Tujuan dari penelitian ini adalah untuk menganalisis pengaruh karakteristik anak, karakteristik keluarga, dan kesejahteraan keluarga terhadap kualitas lingkungan pengasuhan pada anakusia prasekolah. Contoh terdiri atas 120 anak pendidikan prasekolah di Kota Sungai Penuh, Provinsi Jambi yang dipilih dengan cara acak. Data dikumpulkan melalui wawancara dan pengamatan, serta dianalisis dengan analisis deskriptif, uji korelasi, dan uji regresi linear berganda. Berdasarkan indikator garis kemiskinan, keluarga dikelompokkan menjadi keluarga sejahtera dan keluarga tidak sejahtera. Hasil penelitian menunjukkan bahwa $45,8 \%$ keluarga termasuk dalam sejahtera dan 54,2\% keluarga termasuk tidak sejahtera. Kualitas lingkungan pengasuhan diukur menggunakan skala Home Observation for Measurement of the Environment dan dikategorikan menjadi baik dan kurang baik. Orang tua memberikan stimulasi bahasa, sikap tanggap, dan modeling dalam kualitas baik, sedangkan stimulasi belajar, lingkungan fisik, stimulasi akademik, variasi stimulasi, dan penerimaan dengan kualitas yang kurang baik. Kualitas lingkungan pengasuhan dipengaruhi secara signifikan oleh usia anak, besar keluarga, pendidikan ibu, jenis kelamin anak, dan kesejahteraan keluarga.
\end{abstract}

Kata kunci: anak usia prasekolah, HOME, kemiskinan, pendidikan prasekolah, pengasuhan

\section{Family Welfare and Home Environment Quality on Preschool Aged Children}

\section{Abstract}

The aim of the research was to analyze the influence of child characteristics, family characteristics, and family welfare on quality of home environment on preschool aged children. The samples involved 120 formal and nonformal preschool age children in Sungai Penuh District, Jambi Province that were chosen by stratified random sampling. Data was collected by interview and observation, and also was analyzed by descriptive analysis, correlation test, and multiple linear regression test. Based on poverty line indicator, families were divided into welfare families and nonwelfare families. The results showed that $45,8 \%$ families was welfare and $54,2 \%$ families was nonwelfare. The quality of home environment was measured byscale of Home Observation for Measurement of the Environment (HOME) and was divided into good and less. Parent provided language stimulation, responsivisity, and modeling into good quality, while the availability of learning materials, physical environment; academic stimulation, variety of stimulation, and acceptance into less quality. The quality of home environment was influenced by child's age and sex, family size, maternal education, and family welfare.

Keywords: early childhood education, HOME, parenting, poverty, preschool age children

\section{PENDAHULUAN}

Kemiskinan merupakan salah satu masalah ekonomi yang dihadapi oleh hampir seluruh negara di dunia termasuk juga Indonesia. Kemiskinan menjadi akar masalah dari tidak optimalnya perkembangan anak. Menurut Aber et al. (1997), anak yang hidup dalam kemiskinan lebih beresiko untuk mengalami masalah perkembangan. Pengaruh kemiskinan pada perkembangan anak bergantung pada waktu terjadinya masalah tersebut. Brooks-Gunn dan Duncan (1997) menyebutkan anak yang mengalami kemiskinan sejak usia prasekolah memiliki kualitas perkembangan yang lebih rendah dibandingkan dengan anak yang mengalami kemiskinan pada usia remaja atau dewasa.

Salah satu upaya yang dapat dilakukan untuk mengurangi dampak kemiskinan terhadap perkembangan anak adalah optimalisasi peran keluarga dalam memberikan stimulasi pada anak. Keluarga berperan penting dalam menentukan perkembangan anak (Andrade et al., 2005; Camargo-Figuera, 2014) melalui pemenuhan fungsi instrumental dan fungsi ekspresif (Finley, Mira, \& Scfwartz, 2008). Fungsi instrumental merujuk pada fungsi untuk mencari nafkah yang menjadi tanggung 
jawab ayah sebagai kepala keluarga, sedangkan fungsi ekspresif merujuk pada fungsi untuk melakukan pengasuhan yang menjadi tanggung jawab ibu sebagai pengasuh utama. Ketidakmampuan keluarga dalam menjalankan fungsi instrumental mendorong munculnya masalah kemiskinan. Masalah kemiskinan dapat menghambat keluarga dalam memenuhi fungsi ekspresifnya. Menurut Dearing dan Taylor (2007), kemiskinan membuat keluarga kesulitan dalam menyediakan lingkungan pengasuhan yang berkualitas.

Penelitian kesejahteraan keluarga dan kualitas lingkungan pengasuhan telah banyak dilakukan secara parsial, seperti Hastuti dan Alfiasari (2008); Rahmaulina dan Hastuti (2008); Latifah, Alfiasari, dan Hernawati (2009); Latifah, Hastuti, dan Latifah (2010); dan Hastuti, Fiernanti, dan Guhardja (2011). Berdasarkan pemaparan tersebut, penelitian ini bertujuan menganalisis ke-sejahteraan keluarga dan kualitas lingkungan pengasuhan pada anak usia prasekolah. Penelitian juga dilakukan untuk menganalisis hubungan antarvariabel penelitian. Selanjutnya, penelitian dilakukan untuk menganalisis pengaruh karakteristik anak, karaktersitik keluarga, dan kesejahteraan keluarga terhadap kualitas lingkungan pengasuhan pada anak usia prasekolah.

\section{METODE}

Penelitian ini menggunakan desain cross sectional dan dilakukan pada bulan April sampai dengan bulan Juni tahun 2014. Contoh penelitian dipilih secara acak yaitu 120 anak yang mengikuti pendidikan prasekolah di Kota Sungai Penuh, Provinsi Jambi. Selanjutnya, data yang dikumpulkan dalam penelitian ini merupakan data primer, terdiri atas: karakteristik anak, karakteristik keluarga, kesejahteraan keluarga, dan kualitas lingkungan pengasuhan. Pengumpulan data dilakukan dengan wawancara pada ibu dan observasi lingkungan rumah.

Karakteristik anak terdiri atas jenis kelamin dan usia anak. Karakteristik keluarga meliputi tipe keluarga, besar keluarga, usia ayah dan ibu, pendidikan ayah dan ibu, pekerjaan ayah dan ibu, pendapatan keluarga, dan pengeluaran keluarga. Kesejahteraan keluarga diukur dengan menggunakan indikator garis kemiskinan BPS. Indikator ini membandingkan antara pengeluaran keluarga (Rp/kapita/bulan) dengan garis kemiskinan perkotaan Provinsi Jambi tahun 2014 yaitu Rp379.183,00. Berdasarkan indikator garis kemiskinan BPS, keluarga dibedakan menjadi dua kategori yaitu keluarga sejahtera dan tidak sejahtera. Keluarga sejahtera adalah keluarga yang memiliki pengeluaran (Rp/kapita/bulan) lebih besar dari garis kemiskinan, sedangkan keluarga tidak sejahtera adalah keluarga yang memiliki pengeluaran (Rp/kapita/bulan) kurang dari atau sama dengan garis kemiskinan.

Kualitas lingkungan pengasuhan diukur dengan skala Home Observation for Measurement of the Environment (HOME) (Caldwell \& Bradley, 2003). Instrumen ini terdiri atas delapan subskala yaitu ketersediaan bahan ajar (learning materials); stimulasi bahasa (language stimulation); lingkungan fisik (physical environment); sikap tanggap (responsivity); stimulasi akademik (academic stimulation); modeling (modeling); variasi stimulasi (variety); dan penerimaan (acceptance). Skala HOME terdiri atas 55 indikator dengan dua pilihan jawaban yaitu ya (skor 1) dan tidak (skor 0). Instrumen HOME telah reliabel dan valid dengan nilai Cronbach's alpha sebesar 0.900. Skor yang diperoleh dijumlahkan berdasarkan subskala (skor subskala) dan total (skor skala). Berdasarkan median (Tabel 1), skor yang diperoleh dikategorikan menjadi dua kategori yaitu kurang baik (skor<median) dan baik (skor $\geq$ median).

Analisis data yang digunakan dalam penelitian ini adalah analisis deskriptif, uji korelasi, dan uji regresi linear berganda. Analisis deskriptif untuk menghitung jumlah dan persentase dari kategori, nilai minimum, nilai maksimum, nilai rata-rata, dan standar deviasi dari setiap variabel penelitian. Uji korelasi Pearson dan uji korelasi Spearman untuk menganalisis hubungan antarvariabel penelitian. Selanjutnya, uji regresi linear berganda digunakan untuk menganalisis pengaruh karakteristik anak, karakteristik keluarga, dan kesejahteraan keluarga terhadap kualitas lingkungan pengasuhan.

Tabel 1 Penilaian skala HOME

\begin{tabular}{clcc}
\hline No & Subskala & $\begin{array}{c}\text { Skor } \\
\text { tertinggi }\end{array}$ & Median \\
\hline 1 & Ketersediaan bahan ajar & 11 & 8 \\
2 & Stimulasi bahasa & 7 & 6 \\
3 & Lingkungan fisik & 7 & 6 \\
4 & Sikap tanggap & 7 & 6 \\
5 & Stimulasi akademik & 5 & 4 \\
6 & Modeling & 5 & 3 \\
7 & Variasi stimulasi & 9 & 8 \\
8 & Penerimaan & 4 & 4 \\
\hline & Skala HOME & 55 & 40 \\
\hline
\end{tabular}

Sumber: Caldw ell dan Bradley (2003) 


\section{HASIL}

\section{Karakteristik Anak dan Keluarga}

Anak pendidikan prasekolah $(54,2 \%)$ yang terlibat dalam penelitian ini berjenis kelamin laki-laki. Usia anak berada pada rentang 42-65 bulan dengan rata-rata usia adalah 55 bulan. Tipe keluarga dari anak pendidikan prasekolah adalah keluarga inti $(51,7 \%)$. Keluarga $(49,2 \%)$ berukuran sedang (jumlah anggota keluarga 56 orang). Usia ayah (84,2\%) dan ibu $(93,3 \%)$ berada pada kategori dewasa muda (usia 20-40 tahun). Seluruh ayah dan separuh ibu bekerja. Tiga dari sepuluh ayah bekerja di sektor formal. Persentase tertinggi untuk pendidikan ayah (55,8\%) dan ibu $(55,8 \%)$ dari anak pendidikan prasekolah adalah SMA/sederajat. Nilai ratarata dan standar deviasi karakteristik keluarga disajikan pada Tabel 2.

\section{Kesejahteraan Keluarga}

Berdasarkan indikator Garis Kemiskinan, keluarga dikategorikan menjadi keluarga sejahtera dan tidak sejahtera. Keluarga sejahtera adalah keluarga yang mampu memenuhi kebutuhan dasar (makanan dan bukan makanan) yang ditandai dengan pengeluaran keluarga (Rp/kapita/bulan) lebih besar dibandingkan dengan garis kemiskinan BPS. Sementara itu, keluarga tidak sejahtera adalah keluarga yang tidak mampu memenuhi kebutuhan dasar (makanan dan bukan makanan) yang ditandai dengan pengeluaran keluarga (Rp/kapita/bulan) kurang dari atau sama dengan garis kemiskinan BPS. Hasil penelitian menemukan bahwa tiga dari empat keluarga pendidikan prasekolah formal termasuk dalam kategori keluarga sejahtera (Tabel 15). Hasil ini mengindikasikan bahwa sebanyak 45,8\% keluarga termasuk dalam keluarga sejahtera dan $54,2 \%$ keluarga termasuk dalam keluarga tidak sejahtera.

Tabel 2 Nilai rata-rata dan standar deviasi karakteristik keluarga

\begin{tabular}{lc}
\hline Karakteristik & $\begin{array}{c}\text { Rata-rata } \pm \text { Standar } \\
\text { deviasi }\end{array}$ \\
\hline Besar keluarga (orang) & $4.7 \pm 1.1$ \\
Usia ayah (tahun) & $35.9 \pm 4.4$ \\
Usia ibu (tahun) & $32.8 \pm 4.7$ \\
$\begin{array}{l}\text { Pendidikan ayah } \\
\text { (tahun) }\end{array}$ & $12.6 \pm 2.7$ \\
$\begin{array}{l}\text { Pendidikan ibu (tahun) } \\
\text { Pendapatan keluarga }\end{array}$ & $12.6 \pm 2.6$ \\
$\begin{array}{l}\text { (Rp/kapita/bulan) } \\
\text { Pengeluaran keluarga } \\
\text { (Rp/kapita/bulan) }\end{array}$ & $477.533,29 \pm 2766,27 \pm 474.277,65$ \\
\hline
\end{tabular}

\section{Kualitas Lingkungan Pengasuhan}

Ketersediaan bahan ajar. Ketersediaan bahan ajar diukur berdasarkan kepemilikan mainan yaitu mainan untuk belajar tentang warna, ukuran, dan bentuk; tiga atau lebih puzzle; rekaman dan media untuk memutar hasil rekaman; mainan bebas ekspresi; mainan untuk melatih motorik halus; mainan untuk belajar angka. Ketersediaan bahan ajar juga diukur berdasarkan kepemilikan buku yaitu buku untuk anak dan buku yang dapat dibaca oleh orang tua. Selain itu, ketersediaan bahan ajar juga diukur berdasarkan kebiasaan orang tua dalam membeli dan membaca koran setiap hari, berlangganan minimal satu majalah, dan mendorong anak untuk belajar tentang bentuk.

Seluruh anak pendidikan prasekolah telah memiliki mainan bebas ekspresi. Sekitar 80 persen anak pendidikan prasekolah telah memiliki media untuk memutar hasil rekaman, mainan untuk belajar angka, dan mainan untuk melatih motorik halus. Sekitar 50 persen anak pendidikan prasekolah juga telah mempunyai tiga atau lebih puzzle dan anak juga didorong untuk belajar tentang bentuk-bentuk. Akan tetapi, masih banyak terdapat anak pendidikan prasekolah yang tidak memiliki mainan untuk belajar tentang warna, ukuran, dan bentuk $(55,0 \%)$ dan buku anak $(58,3 \%)$. Sebagian besar keluarga juga tidak memiliki buku keluarga $(76,7 \%)$, kebiasaan keluarga untuk membeli dan membaca koran setiap hari $(65,0 \%)$, serta kebiasaan berlangganan majalah $(85,0 \%)$.

Bahan ajar yang disediakan oleh orang tua untuk anak pendidikan prasekolah termasuk dalam kategori kurang baik $(64,2 \%)$ dengan nilai rata-rata skor sebesar 6,1 . Nilai rata-rata skor yang diperoleh pada subskala ketersediaan bahan ajar lebih kecil dibandingkan dengan nilai median $(8,0)$. Hasil ini menunjukkan bahwa rata-rata orang tua dari anak pendidikan prasekolah belum optimal dalam menyediakan bahan ajar untuk menunjang perkembangan anaknya.

Stimulasi Bahasa. Stimulasi bahasa diukur dengan tujuh indikator yang terdiri atas penyediaan mainan yang dapat membantu anak belajar tentang nama binatang; pengajaran tentang huruf abjad; pengajaran tentang tata krama sederhana (salam, tolong, terima kasih, dan maaf); pemberian kesempatan pada anak untuk bercerita tentang pengalaman dan orang tua mendengarkan cerita anak; pemberian kesempatan pada anak untuk memilih menu sarapan atau makan siang 
sendiri; penggunaan tata bahasa dan pelafalan yang benar kepada anak; dan penyaluran perasaan positif tentang anak melalui suara orang tua.

Seluruh orang tua dari anak pendidikan prasekolah formal dan nonformal telah menyediakan mainan yang dapat mengajarkan anak tentang nama binatang, seperti puzzle binatang, boneka binatang, dan buku cerita yang berisi tentang binatang. Seluruh orang tua juga telah mengajarkan anak mengenai tata krama sederhana seperti mengucapkan salam ketika masuk/keluar rumah, tolong ketika meminta bantuan orang lain, terima kasih setelah mendapatkan bantuan dari orang lain, dan maaf setelah melakukan kesalahan. Selanjutnya, orang tua $(99,2 \%)$ juga memberikan kesempatan pada anak untuk bercerita tentang pengalamannya dan orang tua mendengarkan cerita yang disampaikan oleh anak. Orang tua (99,2\%) juga menggunakan tata bahasa dan pelafalan yang benar dan suara yang digunakan orang tua juga menyalurkan perasaan yang positif ketika berbicara dengan anak. Ketika sarapan atau makan siang, orang tua $(78,3 \%)$ juga memberikan kesempatan kepada anak untuk memilih menu. Orang tua $(75,0 \%)$ juga telah mendorong anak untuk belajar tentang huruf abjad melalui penyediaan media belajar tentang huruf abjad, seperti poster, buku, dan karpet bergambar.

Sebagian besar orang tua dari anak pendidikan prasekolah $(85,8 \%)$ telah memberikan stimulasi bahasa pada kategori baik dengan nilai rata-rata sebesar 6,5. Nilai rata-rata skor yang diperoleh lebih besar daripada median $(6,0)$. Hasil ini mengindikasikan bahwa rata-rata orang tua telah memberikan stimulasi bahasa yang baik untuk anaknya.

Lingkungan fisik. Lingkungan fisik diukur berdasarkan struktur bangunan rumah, tempat bermain luar rumah, keadaan dalam rumah, kenyamanan lingkungan di sekitar rumah, luas rumah, kepadatan dalam rumah, dan kebersihan rumah. Orang tua dari anak pendidikan prasekolah formal telah menyediakan rumah dengan struktur yang aman dan bebas dari bahaya $(90,8 \%)$, tempat bermain anak (luar rumah) yang aman (85,8\%), pencahayaan yang baik sehingga rumah tidak gelap $(66,7 \%)$, lingkungan di sekitar rumah nyaman $(83,3 \%)$, rumah tidak sempit $(67,5 \%)$, rumah tidak dipenuhi oleh alat rumah tangga $(71,7 \%)$, serta ruang dalam rumah bersih dan tertata rapi $(66,75)$.
Orang tua dari anak pendidikan prasekolah $(59.2 \%)$ telah menyediakan lingkungan fisik yang berkualitas baik untuk anaknya dengan nilai rata-rata sebesar 5.3. Nilai rata-rata yang diperoleh lebih kecil dari median $(6,0)$. Hasil ini mengindikasikan bahwa rata-rata orang tua belum mampu memberikan lingkungan fisik yang berkualitas baik untuk anaknya.

Sikap tanggap. Sikap tanggap diukur dengan tujuh indikator, yaitu: kegiatan orang tua menggendong/memangku/memeluk anak selama 10-15 menit per hari, berbicara pada anak, menjawab pertanyaan atau permintaan anak dengan kata-kata, menanggapi perkataan anak dengan kata-kata, memuji anak, membelai/mencium/merangkul anak, dan membantu anak untuk menunjukkan kepandaiannya. Lebih dari 90 persen orang tua telah berbicara pada anak sekurang-kurangnya dua kali selama kunjungan, menjawab pertanyaan atau permintaan anak dengan katakata, menanggapi perkataan anak dengan katakata, membelai/mencium/merangkul anak sekurang-kurangnya sekali selama kunjungan, dan membantu anak untuk menunjukkan kepandaiannya selama kunjungan. Indikator pada subskala sikap tanggap yang belum dipenuhi secara optimal adalah menggendong/ memangku/memeluk anak selama 10-15 menit per hari. Satu dari tiga orang tua tidak selalu menggendong/memangku/memeluk anak selama 10-15 menit per hari terutama pada anak pendidikan prasekolah yang telah memiliki adik.

Sikap tanggap yang diberikan oleh orang tua pada anak pendidikan prasekolah tergolong dalam kategori baik $(99,2 \%)$ dengan nilai ratarata skor sebesar 6,6. Nilai rata-rata skor yang diperoleh lebih besar daripada median $(6,0)$. Hasil ini mengindikasikan bahwa rata-rata orang tua telah memberikan sikap tanggap yang baik untuk anaknya.

Stimulasi akademik. Stimulasi akademik diukur dengan lima indikator, yaitu: dorongan orang tua pada anak untuk belajar tentang warna, pembicaraan yang berpola (contoh puisi anak, do'a, lagu, dan iklan televisi), konsep ruang (contoh: besar-kecil, luar-dalam, dan atas-bawah), angka (contoh: berhitung), dan membaca kata-kata sederhana. Orang tua dari anak pendidikan prasekolah telah mendorong anak untuk belajar tentang pembicaraan yang berpola $(98,3 \%)$ dan angka (100,0\%). Akan tetapi, masih banyak orang tua dari anak pendidikan prasekolah yang belum mendorong anak untuk belajar tentang warna $(80,0 \%)$, 
belajar tentang konsep ruang (91,7\%), dan belajar membaca kata-kata sederhana $(43,3 \%)$.

Stimulasi akademik yang diberikan oleh orang tua ke anak pendidikan prasekolah termasuk dalam kategori kurang baik $(80,0 \%)$ dengan rata-rata skor sebesar 2,9. Nilai ratarata yang diperoleh lebih kecil dari median $(4,0)$. Hasil ini mengindikasikan bahwa rata-rata orang tua belum mampu memberikan stimulasi akademik yang berkualitas baik untuk anaknya. Capaian stimulasi akademik yang belum bisa disediakan dengan baik oleh orang tua adalah pemberian stimulasi untuk mendorong anak belajar tentang warna dan konsep ruang. Orang tua belum optimal dalam mengajarkan anak untuk belajar tentang nama-nama warna sehingga banyak anak yang belum mampu menjawab tentang nama-nama warna dengan benar. Orang tua juga belum optimal dalam mengajarkan anak tentang konsep ruang seperti besar-kecil, luar-dalam, dan atas-bawah sehingga banyak anak yang belum mampu menjawab dengan benar tentang konsep ruang.

Modeling. Modeling diukur dengan lima indikator. Indikator tersebut terdiri atas meminta anak untuk menunggu waktu makan/jajan yang tepat; menggunakan televisi secara bijaksana; memberikan kesempatan pada anak untuk menunjukkan kekecewaan atau kemarahannya tanpa mendapatkan hukuman fisik; memperbolehkan anak memukul orang tuanya tanpa dibalas dengan pukulan yang sama; dan memperkenalkan tamu pada anak. Seluruh orang tua telah mengenalkan tamu yang berkunjung ke rumah pada anak. Sebagian besar orang tua $(99,2 \%)$ telah memberikan kesempatan pada anak untuk menunjukkan kekecewaan atau kemarahannya tanpa mendapatkan hukuman fisik. Anak juga dapat memukul orang tuanya tanpa dibalas dengan pukulan yang sama kerasnya (98,3\%). Orang tua $(55,5 \%)$ masih belum mampu meminta anak untuk menunggu waktu makan atau jajan yang tepat. Orang tua $(67,5 \%)$ juga masih belum mampu dalam mengatur penggunaan televisi di rumah.

Orang tua dari anak pendidikan prasekolah telah baik dalam memberikan contoh berperilaku pada anak $(98,3 \%)$ dengan nilai rata-rata skor adalah 3,8. Nilai rata-rata skor yang diperoleh lebih besar daripada median $(3,0)$ yang menunjukkan bahwa orang tua telah baik dalam memberikan contoh berperilaku pada anak pendidikan prasekolah.

Variasi Stimulasi. Variasi stimulasi kepada anak diukur dengan sembilan indikator yaitu penyediaan alat musik (mainan atau sungguhan), jalan-jalan bersama keluarga, bepergian jauh, berkunjung ke museum (ilmiah, sejarah, atau seni), pemberian dorongan pada anak untuk mengambil dan mengembalikan mainannya sendiri tanpa dibantu, penggunaan struktur kalimat dan kosa kata yang kompleks dan panjang ketika berbicara pada anak, pemajangan/penempelan hasil karya anak di rumah, makan bersama keluarga, dan pemberian kesempatan pada anak untuk memilih makanan yang digemarinya di tempat penjualan makanan.

Sebagian besar orang tua dari anak pendidikan prasekolah formal telah mengajak anak untuk jalan-jalan dan berbelanja sekurang-kurangnya sekali dalam seminggu $(83,3 \%)$, mengajak anak untuk makan bersama keluarga paling tidak sekali dalam satu hari $(95,0)$, memperbolehkan anak untuk memilih makanan yang digemarinya di tempat penjualan makanan $(86,7 \%)$, dan berbicara dengan menggunakan struktur kalimat dan kosa kata yang kompleks (77,5\%). Akan tetapi, sebagian besar orang tua belum mampu dalam mengajak anak ke museum $(100,0 \%)$, menyediakan alat musik mainan atau alat musik sungguhan (62,5\%), mengajak anak bepergian jauh (79,2\%), mengajarkan anak untuk mengambil dan mengembalikan mainannya sendiri tanpa bantuan $(40,8 \%)$, dan memajang hasil karya anak di rumah $(97,5 \%)$.

Variasi stimulasi yang diberikan orang tua termasuk dalam kategori kurang baik $(99,2 \%)$ dengan rata-rata skor sebesar 4,6. Nilai ratarata skor lebih kecil dibandingkan dengan nilai median $(8,0)$. Hasil ini mengindikasikan bahwa orang tua dari anak pendidikan prasekolah belum mampu memberikan stimulasi dengan teknik yang bervariasi pada anak.

Penerimaan. Penerimaan diukur berdasarkan sikap orang tua untuk tidak memberikan anak hukuman fisik lebih dari sekali minggu kemarin, tidak memarahi anak baik melalui kata-kata maupun isyarat, tidak membatasi/melarang/menarik paksa/ mencubit anak secara fisik, dan tidak menampar/menempeleng anak. Sebagian besar orang tua tidak memarahi anak baik melalui kata-kata maupun isyarat $(73,3 \%)$, tidak membatasi/melarang/menarik paksa/mencubit anak secara fisik $(77,5 \%)$, dan orang tua juga tidak menampar/menempeleng anak selama kunjungan (99,2\%). Akan tetapi, orang tua dari anak pendidikan prasekolah masih memberikan hukuman fisik pada anak lebih dari sekali minggu kemarin $(62,5 \%)$. 
Secara umum, kualitas penerimaan pada tujuh dari sepuluh orang tua termasuk dalam kategori kurang baik dengan rata-rata skor sebesar 2,9. Nilai rata-rata skor ini lebih kecil dibandingkan dengan median yaitu 4,0 yang menunjukkan bahwa orang tua belum menerima anak dengan kualitas baik. Hal ini dapat terjadi karena masih banyak orang tua yang memberikan hukuman fisik pada anak.

Skala kualitas lingkungan pengasuhan. Hasil penelitian menunjukkan bahwa lebih dari separuh orang tua $(52,5 \%)$ memberikan lingkungan pengasuhan pada kualitas yang kurang baik. Nilai rata-rata skor yang diperoleh $(38,7)$ lebih rendah dibandingkan dengan nilai median (40,0). Berdasarkan pemaparan hasil penilaian subskala dan skala kualitas lingkungan pengasuhan maka dapat disimpulkan bahwa kualitas lingkungan pengasuhan yang telah disediakan dengan baik oleh orang tua dari anak pendidikan prasekolah adalah pemberian stimulasi bahasa, sikap tanggap pada anak, dan pemberian contoh perilaku positif pada anak (modeling).

\section{Hubungan antara Karakteristik Anak, Karakteristik Keluarga, dan Kesejahteraan Keluarga dengan Kualitas Lingkungan Pengasuhan}

Kualitas lingkungan pengasuhan yang disediakan orang tua untuk anak pendidikan prasekolah berhubungan signifikan dengan tipe keluarga $(r=-0,351, p<0,01)$, besar keluarga $) r=-$ $0,268, \quad p<0,01)$, pendidikan ayah $(r=0,653$, $\mathrm{p}<0,01)$ dan ibu $(r=0,720, \quad p<0,01)$, jenis pekerjaan ayah $(r=0,625, \quad p<0,01)$, status pekerjaan ibu $(r=0,187, p<0,05)$, pendapatan keluarga per kapita per bulan $(r=0,701, p<0,01)$, pengeluaran keluarga per kapita per bulan $(r=0,785, p<0,01)$, serta kesejahteraan keluarga berdasarkan indikator garis kemiskinan BPS $(r=0,818, p<0,01)$. Usia dan jenis kelamin anak tidak berhubungan signifikan dengan kualitas lingkungan pengasuhan $(p>0,05)$.

Tipe keluarga dan besar keluarga berhubungan signifikan negatif dengan kualitas lingkungan pengasuhan. Kualitas lingkungan pengasuhan yang disediakan orang tua semakin baik pada keluarga dengan tipe keluarga inti dan pada keluarga dengan jumlah anggota keluarga sedikit. Pendidikan ayah dan ibu berhubungan signifikan positif dengan kualitas lingkungan pengasuhan. Lingkungan pengasuhan semakin berkualitas seiring bertambahnya lama ayah dan ibu mengikuti pendidikan formal. Jenis pekerjaan ayah dan status pekerjaan ibu berhubungan signifikan positif dengan kualitas lingkungan pengasuhan. Hasil ini menunjukkan bahwa kualitas lingkungan pengasuhan akan semakin baik pada keluarga dengan ayah bekerja di sektor formal dan pada keluarga dengan ibu bekerja.

Pekerjaan ayah dan ibu dapat menambah pendapatan keluarga sehingga keluarga memiliki sumber daya yang dapat digunakan untuk memenuhi kebutuhannya. Pendapatan keluarga yang semakin besar mendorong meningkatnya pengeluaran keluarga. Pengeluaran keluarga yang semakin besar meningkatkan kemungkinan keluarga untuk sejahtera. Semakin besar pendapatan dan pengeluaran keluarga serta semakin sejahtera keluarga tersebut maka semakin baik kualitas lingkungan pengasuhan yang dapat disediakan keluarga untuk anak.

\section{Pengaruh Karakteristik Anak, Karakteristik Keluarga, dan Kesejahteraan Keluarga terhadap Kualitas Lingkungan Pengasuhan}

Pengaruh karakteristik anak, karakteristik keluarga, dan kesejahteraan keluarga terhadap kualitas lingkungan pengasuhan dianalisis dengan analisis regresi linear berganda. Analisis ini menggunakan skor kualitas lingkungan pengasuhan sebagai variabel $Y$ dan usia anak, besar keluarga, usia ibu, pendidikan ibu, pendapatan keluarga per kapita, jenis kelamin anak, status pekerjaan ibu, dan kesejahteraan keluarga sebagai variabel $\mathrm{X}$.

Model yang digunakan untuk menganalisis pengaruh karakteristik anak, karakteristik keluarga, dan kesejahteraan keluarga terhadap kualitas lingkungan pengasuhan yang disediakan orang tua untuk anak pendidikan prasekolah memiliki koefisien determinasi (adjusted $R$ square) sebesar 0,774. Koefisien ini menunjukkan bahwa 77,4 persen varian kualitas lingkungan pengasuhan dari anak pendidikan prasekolah dapat dijelaskan oleh perubahan variabel yang ada di dalam model. Sisanya yaitu sebesar 22,6 persen dipengaruhi oleh variabel yang tidak ada dalam model.

Hasil analisis menemukan bahwa kualitas lingkungan pengasuhan yang disediakan orang tua untuk anak pendidikan prasekolah dipengaruhi secara signifikan positif oleh usia anak, lama pendidikan ibu, jenis kelamin anak, dan kesejahteraan keluarga (Tabel 3). Akan tetapi, secara signifikan negatif, kualitas lingkungan pengasuhan dipengaruhi oleh besar keluarga. Kualitas lingkungan pengasuhan menurun dengan bertambahnya jumlah anggota keluarga. 
Tabel 3 Koefisien regresi untuk menganalisis pengaruh karakteristik keluarga, karakteristik anak, dan kesejahteraan keluarga terhadap kualitas lingkungan pengasuhan

\begin{tabular}{lrc}
\hline \multirow{2}{*}{ Variabel bebas } & \multicolumn{2}{c}{ Total } \\
\cline { 2 - 3 } & \multicolumn{1}{c}{$\beta$} & Sig. \\
\hline Usia anak (bulan) & 0,099 & $0,030^{*}$ \\
Besar keluarga (orang) & $-0,113$ & $0,025^{*}$ \\
Usia ibu (tahun) & 0,035 & 0,441 \\
Lama pendidikan ibu & 0,316 & $0,000^{* *}$ \\
(tahun) & & \\
Pendapatan keluarga & 0,051 & 0,489 \\
(Rp/kapita/bulan) & & \\
Jenis kelamin anak (0: & 0,103 & $0,024^{*}$ \\
laki-laki, 1: perempuan) & & \\
Status pekerjaan ibu (0: & $-0,022$ & 0,657 \\
tidak bekerja, 1: bekerja) & & \\
Kesejahteraan keluarga & 0,579 & $0,000^{* *}$ \\
(0: tidak sejahtera, 1: & & \\
sejahtera) & & \\
\hline R & & 0.889 \\
R Square & & 0.790 \\
Adjusted R Square & & 0.774 \\
F & & 52.07 \\
Sig & & 0.000 \\
\hline Keterangan: \\
*signifikan padap<0,05, **signifikan pada
\end{tabular}

\section{PEMBAHASAN}

Optimalisasi peran keluarga dalam memberikan stimulasi pada anak dilakukan sebagai upaya untuk untuk mengurangi dampak kemiskinan terhadap perkembangan anak pendidikan prasekolah. Langkah awal yang diperlukan untuk memperbaiki kualitas lingkungan adalah pemahaman mengenai kondisi dari lingkungan tersebut. Lingkungan keluarga berperan dalam mengoptimalkan perkembangan anak melalui penyediaan lingkungan pengasuhan yang berkualitas. Kualitas lingkungan pengasuhan dinilai dari ketersediaan bahan ajar, stimulasi bahasa; lingkungan fisik; sikap tanggap; stimulasi akademik; modeling; variasi stimulasi; dan penerimaan. Orang tua dari anak pendidikan prasekolah telah mampu menyediakan lingkungan pengasuhan berkualitas baik pada subskala stimulasi bahasa, sikap tanggap, dan modeling.

Orang tua telah memberikan stimulasi bahasa pada anak pendidikan prasekolah dengan baik. Orang tua telah mengenalkan binatang pada anak melalui poster; mengajarkan anak untuk mengucapkan salam, tolong, terima kasih, dan maaf; menggunakan bahasa dan pelafalan yang benar; memberikan kesempatan anak untuk bercerita dan orang tua mendengarkan; serta menyalurkan perasaan positif pada anak sehingga anak senang untuk berbicara dengan orang tuanya. Meskipun demikian, orang tua masih perlu mengoptimalkan stimulasi bahasa terutama dalam mengajarkan anak tentang huruf abjad. Anak usia prasekolah akan memasuki sekolah yang sesungguhnya sehingga orang tua hendaknya segera mempersiapkan anak dengan cara mengenalkan huruf abjad pada anak. Selain itu, orang tua juga hendaknya memberikan kesempatan pada anak untuk mengambil keputusan seperti pemberian kesempatan pada anak untuk memilih menu sarapan atau makan siang sendiri.

Orang tua telah memberikan contoh pada anak pendidikan prasekolah dengan baik. Akan tetapi, masih ada indikator dalam subskala ini yang masih perlu ditingkatkan yaitu kebiasaan dalam menonton televisi. Sebagian besar keluarga memiliki televisi dan televisi tersebut disetel setiap saat sehingga banyak anak yang ikut menonton termasuk juga menonton tayangan yang tidak sesuai dengan usianya. Tayangan yang tidak sesuai dengan usia anak dikhawatirkan dapat membawa pengaruh negatif bagi perkembangan anak. Di samping itu, kualitas lingkungan pengasuhan sudah cukup baik pada sikap tanggap orang tua. Orang tua menunjukkan kebanggaannya pada anak melalui pemberian pujian dan juga membantu anak dalam menunjukkan kepandaiannya. Kasih sayang dan kehangatan diperlihatkan melalui pelukan, belaian/ciuman, dan juga pemberian tanggapan atas pertanyaan dan permintaan anak.

Kualitas lingkungan pengasuhan masih belum optimal pada subskala ketersediaan bahan ajar, lingkungan fisik, stimulasi akademik, variasi stimulasi, dan penerimaan. Ketersediaan bahan ajar belum optimal terutama dalam hal ketersediaan mainan dan buku yang dapat digunakan oleh anak untuk belajar. Selain itu, penyediaan bahan ajar juga terhambat karena keluarga tidak memiliki buku keluarga, tidak terbiasa untuk membaca koran/majalah, dan tidak terbiasa untuk mendorong anak belajar tentang bentuk. Mainan dan buku merupakan media yang bisa digunakan oleh orang tua dalam memberikan stimulasi pada anak. Melalui mainan dan buku, anak dapat mempelajari banyak hal seperti warna, bentuk, ukuran, dan angka. Ketidaktersediaan mainan dan buku juga berdampak pada menurunnya jumlah stimulasi akademik yang dapat diberikan untuk anak. Hal ini dapat terjadi karena ketidaktersediaan bahan ajar menjadi salah satu alasan orang tua 
untuk memberikan stimulasi akademik pada anak, seperti menghambat orang tua untuk mengajarkan anak tentang warna dan konsep ruang. Subskala lingkungan fisik juga belum optimal. Lingkungan fisik erat kaitannya dengan kondisi tempat tinggal/rumah anak. Lingkungan fisik yang disediakan oleh keluarga termasuk dalam kategori tidak optimal karena rumah yang ditempati anak dalam penelitian ini dalam keadaan gelap dan monoton, sempit, dipenuhi oleh alat rumah tangga, dan kondisinya juga tidak bersih dan tidak tertata rapi. Kondisi rumah yang seperti ini dapat mengganggu kenyamanan anak dalam belajar. Solari dan Mare (2012) mengemukakan bahwa kondisi rumah yang tidak berkualitas berdampak pada terbatasnya ruang untuk belajar, mengganggu konsentrasi, dan mengganggu tidur sehingga kondisi ini berdampak negatif untuk perkembangan kognitif anak.

Di samping itu, cara pemberian stimulasi kepada anak yang tidak bervariasi juga menurunkan kualitas lingkungan pengasuhan. Hasil penelitian pada subskala variasi stimulasi kepada anak menunjukkan sebagian besar anak tidak memiliki alat musik (mainan atau sungguhan), tidak mengajak anak jalan-jalan, tidak mengajak anak untuk bepergian jauh, tidak mengajak anak ke museum (ilmiah, sejarah, atau seni), dan keluarga juga tidak memajang/menempel hasil karya anak. Permasalahan lain yang mendorong tidak optimalnya kualitas lingkungan pengasuhan yang disediakan oleh keluarga adalah terletak pada subskala penerimaan. Penelitian ini menemukan bahwa masih terdapat orang tua yang memarahi anak baik melalui kata-kata maupun isyarat; membatasi, melarang, menarik paksa, atau mencubit anak secara fisik; dan memberikan hukuman fisik pada anak. Hasil penelaahan pada setiap subskala kualitas pengasuhan menunjukkan masalah utama yang dihadapi oleh keluarga dalam menyediakan lingkungan pengasuhan yang berkualitas adalah tidak tersedianya media yang dapat digunakan dalam memberikan stimulasi untuk perkembangan anak.

Kualitas lingkungan pengasuhan yang disediakan orang tua untuk anak pendidikan prasekolah dipengaruhi oleh usia anak, besar keluarga, lama pendidikan ibu, jenis kelamin anak, dan kesejahteraan keluarga. Usia dan jenis kelamin anak berpengaruh signifikan terhadap kualitas lingkungan pengasuhan. Pengaruh usia terhadap kualitas lingkungan pengasuhan adalah negatif yang mengindikasikan bahwa penambahan usia pada anak sebanyak satu satuan dapat menurunkan kualitas lingkungan pengasuhan sebesar 0,113. Sementara itu, pengaruh jenis kelamin terhadap kualitas lingkungan pengasuhan adalah positif yang menunjukkan bahwa kualitas lingkungan pengasuhan meningkat sebanyak 0,099 satuan pada keluarga yang memiliki anak perempuan. Hasil ini sejalan dengan Holden (2010) bahwa usia dan jenis kelamin anak memengaruhi perilaku anak yang selanjutnya memengaruhi perilaku pengasuhan orang tua.

Besar keluarga berpengaruh signifikan negatif terhadap kualitas lingkungan pengasuhan. Hasil ini mengindikasikan bahwa penambahan jumlah anggota keluarga dapat menurunkan kualitas lingkungan pengasuhan. Jumlah anggota keluarga berhubungan dengan kesejahteraan keluarga. Jumlah anggota keluarga yang semakin sedikit dapat meningkatkan kesejahteraan keluarga. Keluarga yang sejahtera mampu memenuhi kebutuhan dari setiap anggotanya termasuk juga dengan kebutuhan anak. Keluarga sejahtera menentukan kemampuan keluarga dalam menyediakan bahan ajar (contoh: buku, alat permainan edukatif, dan media belajar) dan juga menentukan kemampuan keluarga dalam menyediakan lingkungan fisik yang berkualitas di rumah. Hasil ini sejalan dengan penelitian sebelumnya bahwa jumlah anggota keluarga menentukan kualitas lingkungan pengasuhan. Jumlah anggota keluarga yang semakin banyak dapat menurunkan kualitas lingkungan pengasuhan (Klebanov, Brooks-Gunn, \& Duncan, 1994; Zevalkink, Riksen-Walraven, \& Bradley, 2008).

Pendidikan ibu yang berpengaruh signifikan positif terhadap kualitas lingkungan pengasuhan menjelaskan bahwa penambahan lama ibu dalam mengikuti pendidikan formal dapat meningkatkan kualitas lingkungan pengasuhan. Hasil ini menguatkan pendapat Klebanov, Brooks-Gunn, dan Duncan (1994), dan Zhang (2012) bahwa pendidikan yang tinggi dapat meningkatkan kualitas lingkungan pengasuhan. Pendidikan erat kaitannya dengan pengetahuan dan pendidikan yang tinggi memungkinkan individu untuk mendapatkan pengetahuan yang lebih banyak. Pengetahuan yang dimiliki oleh seorang individu ini akan membimbing individu untuk bersikap. Untuk menjadi pengasuh yang baik, orang tua harus memberikan stimulasi yang tepat pada anak, seperti media yang bisa digunakan dalam pemberian stimulasi dan cara menggunakan media tersebut. Hal ini bisa dilakukan jika orang tua memiliki pengetahuan yang baik dan 
pengetahuan ini bisa diperoleh melalui pendidikan dan juga pengalaman.

Kualitas lingkungan pengasuhan ditentukan juga oleh kesejahteraan keluarga. Kesejahteraan keluarga berpengaruh signifikan positif terhadap kualitas lingkungan pengasuhan. Artinya, lingkungan pengasuhan semakin berkualitas dengan semakin sejahteranya keluarga. Kondisi keluarga yang tidak sejahtera dapat menghambat keluarga dalam menyediakan lingkungan pengasuhan yang berkualitas. Hasil ini konsisten dengan hasil penelitian yang telah dilakukan sebelumnya bahwa ketidaksejahteraan menjadi salah satu penyebab rendahnya kualitas lingkungan pengasuhan (Klebanov, Brooks-Gunn, \& Duncan, 1994; Pachter et al., 2006; Zevalkink, RiksenWalraven, \& Bradley, 2008) karena kondisi ini menyebabkan keluarga tidak mampu menyediakan fasilitas yang memadai untuk anak (Eamon, 2001).

Perbaikan kualitas lingkungan pengasuhan diperlukan sebagai upaya untuk meningkatkan perkembangan anak. Alasannya, ketidakmampuan keluarga dalam memberikan stimulasi pada anak berdampak pada tidak optimalnya perkembangan anak tersebut. Anak yang hidup dalam kemiskinan dan anak yang mendapatkan sedikit stimulasi dari lingkungan rumah memiliki resiko yang lebih besar untuk mengalami masalah perkembangan terutama pada perkembangan kognitif dan perkembangan sosial emosi (Aber et al., 1997; Welsch \& Zimmer, 2010; Harden \& Whittaker, 2011).

\section{SIMPULAN DAN SARAN}

Orang tua telah baik dalam pemberian stimulasi bahasa, lingkungan fisik, sikap tanggap pada anak, dan pemberian contoh perilaku positif pada anak (modeling). Akan tetapi, orang tua masih kurang baik dalam hal penyediaan bahan ajar, stimulasi akademik, variasi stimulasi, dan penerimaan. Kualitas lingkungan pengasuhan meningkat dengan bertambahnya usia anak, lama pendidikan ibu, dan kesejahteraan keluarga. Orang tua juga menyediakan kualitas lingkungan pengasuhan yang semakin baik pada anak yang berjenis kelamin perempuan. Kualitas lingkungan pengasuhan dapat menurun dengan bertambahnya jumlah anggota keluarga.

Kualitas lingkungan pengasuhan yang belum optimal perlu diperbaiki karena kualitas lingkungan pengasuhan menentukan perkembangan anak. Oleh karenanya, penelitian ini menyarankan untuk meningkatkan kualitas lingkungan pengasuhan dengan cara meningkatkan pendidikan perempuan sebagai calon ibu dan peningkatan kesejahteraan keluarga. Orang tua khususnya ayah perlu diajarkan keterampilan tambahan sebagai usaha untuk menambah pendapatan keluarga. Selain itu, penyuluhan mengenai pengasuhan juga diperlukan untuk meningkatkan pengetahuan orang tua dalam merawat dan mengasuh anak.

\section{DAFTAR PUSTAKA}

Aber, J. L., Bennet, N. G., Conley, D. C., \& Li, J. (1997). The effects of poverty on child health and development. Annual Reviews Inc, 18(4), 63-83.

Andrade, S. A., Santos, D. N., Bastos, A. C., Pedromônico, M. R. M., Almeida-Filho, \& Barreto, M. L. (2005). Family environment and child's cognitive development: An epidemiological approach. Rev Saúrde Púrblica, 39(4), 16.

Brooks-Gunn, J., \& Duncan, G. J. (1997). The effects of poverty on children. The Future of Children, 7(2), 55-71.

Caldwell, B. M., \& Bradley, R. H. (2003). Home Inventory Administration Manual. Arkansas, US: University of Arkansas.

Camargo-Fuguera, F., Barros, A. J. D., Santos, I. S., Matijasevich, A., \& Barros, F. C. (2014). Early life determinants of low IQ at age 6 in children from 2004 Pelotas Birth Cohort: A predictive approach. BMC Pediatrics, 14(308), 1-12.

Dearing, T., \& Taylor, B. A. (2007). Home improvement: Within-family association between income and quality of children's home environment. Journal of Applied Developmental Psychology, 28, 427-444. doi: 10.1016/j.appdev. 2007.06.008.

Eamon, M. K. (2001). The Effects of poverty on children's socioemotional development: An ecological systems analysis. Social Work, 46(3), 256-266.

Finley, G. E., Mira, S. D., \& Scfwartz, S. J. (2008). Perceived paternal and maternal involvement: Factor structures, mean differences, and parental roles. Fathering, 6(1), 62-82.

Harden, B. J., \& Whittaker, J. W. (2011). The Early Home Environment and Developmental Outcomes for young Children in the Child Welfare System. 
Children and Youth Services review, 33, 1392-1403.

Hastuti, D., \& Alfiasari. (2008). Stimulasi psikososial dan pengaruhnya pada karakter anak yang bersekolah dan tidak bersekolah di Taman Bermain Semai Benih Bangsa, Kabupaten Aceh Utara, Provinsi NAD. Jurnal Ilmu Keluarga \& Konsumen, 1(2).

Hastuti, D., Fiernanti, D. Y. I., \& Guhardja, S. (2011). Kualitas lingkungan pengasuhan dan perkembangan sosial emosi anak usia balita di daerah rawan pangan. Jur Jurnal IImu Keluarga \& Konsumen, 3(1), 27-34.

Klebanov, P. K., Brooks-Gunn, J., \& Duncan, G. J. (1994). Does neighborhood and family poverty affect mothers' parenting, mental health, and social support?. Journal of Marriage and the Family, 56(2), 441-455.

Latifah, M., Alfiasari, \& Hernawati, N. (2009). Kualitas tumbuh kembang, pengasuhan orang tua, dan faktor risiko komunitas pada anak usia prasekolah wilayah pedesaan di Bogor. Jurnal IImu Keluarga \& Konsumen, 2(2), 143-153.

Latifah, E., Hastuti, D., \& Latifah, M. (2010). Pengaruh pemberian ASI dan stimulasi psikososial terhadap perkembangan sosial-emosi anak balita pada keluarga ibu bekerja an tidak bekerja. Jur. IIm. Kel. \& Kons, 3(1), 35-45.

Pachter, L. M., Auinger, P., Palmer, R., \& Weitzman, M. (2006). Do parenting and the home environment, maternal neighborhood, and chronic poverty affect child behavioral problems differentially in different racial-ethnic groups?. Pediatrics, 117, 1329-1338. doi:10.1542/peds.20051784.

Rahmaulina, N. D, \& Hastuti, D. (2008). Hubungan pengetahuan ibu tentang gizi dan tumbuh kembang anak serta stimulasi psikososial dengan perkembangan kognitif anak usia 2-5 tahun. Jurnal IImu Keluarga \& Konsumen, 1(2), 171-181.

Solari, C. D., \& Mare, R. D. (2012). Housing crowding effects on children's wellbeing. Social Science Research, 41, 464-476. doi:10.1016/j.ssresearch.2011. 09.012.

Welsch, D. M., \& Zimmer, D. M. (2010). The effect of health and poverty on early childhood cognitive development. Atl Econ J, 38, 37-49. doi: 10.1007/s11293009-9198-2.

Zevalkink, J., Riksen-Walraven, J. M., \& Bradley R. H. (2008). The Quality of Children's Home Environment and Attachment Security in Indonesia. The Journal of Genetic Psychology, 169(1), 72-91.

Zhang, X (2012). The effects of parental education and family income on motherchild relationships, father-child relationships, and family environments in the people's republic of China. Family Process, 51(4), 483-497. doi: 10.1111/j.1545-5300.2011.01380.x. 